Volume. 8 Nomor. 2, Mei 2021. p - 2354-8649 I e - 2579-5767

Open Access at: http:/ / ojs.umrah.ac.id/index.php/selat

DOI: https://doi.org/10.31629/selat.v8i2.3649

\title{
PROBLEMATIKA NORMA LANDASAN PARTAI POLITIK INDONESIA
}

\author{
Emy Hajar Abra \\ Fakultas Hukum Universitas Riau Kepulauan \\ my_87_hjf@yahoo.com
}

\begin{abstract}
The interpretation of political parties in the political party law can be used as the heart of the political party law. Unfortunately, the problem of norms related to the basis of political parties is not properly emphasized, on the contrary, it becomes multiple interpretations on the basis of political parties which should be the only source of law in determining the basis of political parties in Indonesia. This clearly causes the weak implementation of the law on political parties. This can certainly be seen how each political party can provide a multi-basic basis on the basis of norms as stated in the political party law. In fact, if examined more deeply, the law on political parties does not give room for multiple interpretations when referring to the definition of political parties.
\end{abstract}

Keywords; Political Parties, Norms, Foundation.

\begin{abstract}
Abstrak
Tafsiran partai politik dalam undang-undang partai politik dapat dijadikan sebagai jantungnya undang-undang partai politik. Sayangnya problematika norma terkait landasan partai politik justru tidak menegaskan dengan baik, sebaliknya menjadi multitafsir pada landasan partai politik yang seharusnya menjadi satu-satunya sumber hukum dalam penetapan landasan partai politik di Indonesia. Hal tersebut jelas menyebabkan lemahnya implementasi undang-undang partai politik. Hal ini tentu dapat dilihat bagaimana masing-masing partai politik dapat memberikan landasan yang multiasas dengan alasan norma sebagaimana tertuang dalam undang-undang partai politik. Padahal jika dikaji lebih dalam, undang-undang partai politik sama sekali tidak memberi ruang pada multitafsir jika mengacu pada definisi partai politik.
\end{abstract}

Kata Kunci ; Partai Politik, Norma, Dasar. 


\section{PENDAHULUAN}

Asas atau dasar partai politik adalah acuan dalam pergerakan kehidupan partai politik berserta anggota-anggotanya. Dengan asas, sebuah partai politik akan terlihat bentuknya, bentuk disini adalah kemana arah partai politik akan memainkan fungsinya, apa yang akan di sosialisasikan ke masyarakat, sikap dan orientasi politik seperti apa yang akan dibentuk, masyarakat seperti apa yang menjadi basis perjuangan partai, dengan nilai-nilai seperti apa perjuangan itu akan dilakukan, masyarakat seperti apa yang akan dibentuk dan lain sebagainya. Maka dengan dasar asas partai itu begerak melalui program kebijakan partai yang kemudian akan menjadi program kerja nyata yang bisa dirasakan dan dinikmati oleh masyarakat. ${ }^{1}$

Perbincangan terkait asas tunggal, multiasas, atau bahkan tanpa asas seperti Amerika, Turki menjadi perhatian tersendiri, khususnya dalam konsistensi asas terhadap ideologi sebuah negara. Ideologi negara Indonesia memiliki corak yang istimewa. Pancasila sebagai ideologi bangsa Indonesia memiliki perbedaan dengan ideologi kapitalis liberal dan sosialis-komunisme. Salah satunya ketika, sistem komunis yang tidak mengakui hak individu, Pancasila justru mengakui dan melindungi hak-hak individu maupun hak masyarakat, baik dibidang ekonomi maupun politik. ${ }^{2}$

Sigmund Neuman dalam buku karyanya, "modern Political Parties", mengemukakan Partai Politk adalah organisasi dari aktivis-aktivis politik yang berusaha untuk menguasai kekuasaan pemerintahan serta merebut dukungan rakyat melalui persaingan dengan suatu golongan atau golongan-golongan lain yang mempunyai pandangan yang berbeda (A political party is the articulate organization of society's active political agents; those who are concerned with the control of governmental polity power, and who compete for popular support with other group or group holding divergent views). ${ }^{3}$

Tulisan ini akan membahas problematika landasan partai politik indonesia, dengan sumber kajian adalah undang-undang partai politik. Hal ini dirasa perlu melihat bagaimana kondisi partai politik Indonesia yang hampir semua partai politik memiliki ladasan berpartai yang berbeda-beda, atau biasa lebih dikenal dengan multiasas.

\footnotetext{
1Imam Yudhi Prasetya, 2011, Pergeseran Peran Ideologi Dalam Partai Politik, Jurnal Ilmu Politik dan Ilmu Pemerintahan, Tanjungpinang, Universitas Maritime Raja Ali Haji, Vol 1, No 1

2Jimly Asshiddiqie, 2008, Menuju Negara Hukum Yang Demokrastis, Jakarta, Sekretariat Jendal Dan Kepanitraan Mahkamah Konstitusi, HIm 10

${ }^{3}$ Ibid
} 
Multiasas sendiri bukanlah hal yang salah, namun jika dikaji berdasarkan norma dalam ini undang-undang partai politik, nyata terdapat norma multitafsir yang tentunya sangat berpengaruh pada penerapan hukum undang-undang partai politik.

\section{a. Partai Politik}

Dari sisi terminologis, istilah "Partai" membawa gagasan tentang bagian (part). Istilah part masuk ke dalam bahasa Perancis partager, yang artinya membagi-bagi dan masuk dalam bahasa Inggris "partaking" mengadakan kemitraan dan berpartisipasi. ${ }^{4}$ Sedangkan politik sendiri, berasal dari bahasa Yunani yakni polis yang berarti Kota yang berstatus Negara Kota (city state). ${ }^{5}$ Dalam negara Kota orang berinteraksi semata-mata demi mencapai kesejahteraan (kebaikan) di dalam hidupnya.

Partai politik sendiri merupakan sarana bagi warganegara untuk turut serta atau berpartisipasi dalam proses pengelolaan Negara. Secara umum dapat dikatakan bahwa partai politik adalah sesuatu kelompok terorganisir yang anggota-anggotanya mempunyai orientasi, nilai-nilai, dan cita-cita yang sama. Tujuan kelompok ini ialah untuk memperoleh kekuasaan politik dan merebut kedudukan politik (biasanya) dengan cara konstitusional untuk melaksanakan progamnya. ${ }^{6}$

Dalam Al-Qur'an istilah partai disebut dengan perkataan Hizb. Partai (Hizb) secara lughawi mempunyai makna; pertama, suatu komunitas yang memiliki kesamaan konsep dan aktivitas; kedua, kumpulan yang memiliki kekuatan dan persaudaraan; ketiga, kader serta partisipannya. Mengikut pengertian istilah, partai atau hizb adalah suatu kumpulan masyarakat yang menyatu karena memiliki arah, sasaran dan tujuan yang sama. $^{7}$

Dalam kamus istilah Islam, istilah Hizb Allah diartikan sebagai partai Allah SWT, pembela atau pengikut agama Allah SWT. ${ }^{8}$ Dalam istilah modern, hizb atau hizb al-siyasi diartikan dengan sekelompok warganegara yang mempunyai tujuan dan pemikiran yang sama, dan mereka mengatur urusan mereka untuk mencapai tujuan, dengan caracara yang menurut mereka dapat mencapai tujuan tersebut. Di antara mereka ada yang berusaha meraih kedudukan dan kekuasaan politik dalam lingkungan masyarakat mereka. Berdasarkan kepada pengertian secara bahasa dan istilah sebagaimana

\footnotetext{
4Sigit Pamungkas dalam buku Sirajudin \& Winardi, 2015, Dasar-Dasar Hukum Tata Negara Indonesia, Malang, Setara Press, Hlm 283.

5 Imam Hidayat, 2009, Pengantar Teori-Teori Politik, Setara Press, Malang, Hlm 2

6 Miriam Budiardjo, 2012, Dasar Dasar Ilmu Politik Cetakan Kedua, Jakarta, PT. Gramedia Pustaka Utama, Hlm 397

7Muhammad Imarah, 1419, Ma'rakatul Mushthalathat Baina Al-Gharbi Wa Islami, Kairo, Nahdhah Mishr, Hlm 184

8 Moh. E. Hasim, 1987, Kamus Istilah Islam, Bandung, Pustaka, HIm 45
} 
tersebut diatas, maka istilah hizb ini kemudian difahami sebagai partai politik dalam pengertian yang berkembang pada waktu ini. ${ }^{9}$

Sedangkan partai politik yang pertama-tama lahir di Negara Eropa Barat, dengan meluasnya gagasan bahwa rakyat merupakan faktor yang perlu diperhitungkan serta diikut sertakan dalam proses politik, maka partai politik telah lahir secara spontan dan berkembang menjadi penghubung antara rakyat disatu pihak dan pemerintah di pihak lain. Pada Perkembangannya, pada akhir dekade 18an di negara-negara Barat seperti Inggris dan Perancis, kegiatan politik dipusatkan pada kelompok-kelompok politik dalam parleman. Kegiatan-kegiatan ini mula-mula bersifat elitis dan Aristokratis, mempertahankan kepentingan kaum bangsawan terhadap tuntutan-tuntutan Raja. Pada Masa menjelang Perang Dunia I telah timbul klasifikasi partai berdasarakan Ideologi dan ekonomi yaitu partai "kiri” dan partai "kanan”. Konsep "kiri” versus "kanan” telah mengundang banyak perumusan maupun tafsiran yang berbeda-beda. ${ }^{10}$

Analisis semacam ini yang dinamakan "sistem kepartaian" (party sistems) pertama kali dibentangkan oleh Maurice Duverger dalam buku Political Parties. Duverger mengadakan klasifikasi menurut tiga kategori, yaitu sistem partai-tunggal, sistem dwipartai dan sistem multi partai. ${ }^{11}$

1) Sistem Partai-Tunggal

Sementara pengamat yang berpendapat bahwa istilah sistem partai tunggal merupakan istilah yang menyangkal diri sendiri (contradiction in termis), sebab suatu sistem selalu mengandung lebih dari satu bagian (pars).

2) Sistem Dwi-Partai

Pengertian Sistem dwi-partai biasanya diartikan bahwa ada dua partai di antara beberapa partai, yang berhasil memenangkan dua tempat teratas dalam pemilihan umum secara bergiliran dan dengan demikian mempunyai kedudukan dominan.. ${ }^{12}$

3) Sistem Multi-Partai

Umumnya dianggap bahwa keanekaragaman budaya politik suatu masyarakat mendorong pilihan kearah sistem multi-partai. Dianggap bahwa pola multi-

\footnotetext{
${ }_{9}$ Muqoddam cholil, partai islam, http://www.alhikmah.ac.id/soft/Artikel/Kontemporer/partaiislam.pdf, diakses pada 23 Agustus 2017

10 Ibid., Hlm 399

11 Miriam Budiardjo, Op.Cit., Hlm 415

12 Ibid., Hlm 417
} 
partai lebih sesuai dengan pluralitas budaya dan politik dari pada pola dwipartai. ${ }^{13}$

\section{b. Partai Politik Dalam Sistem dan Struktur Politik}

Sistem Politik adalah suatu mekanisme dari seperangkat fungsi atau peranan dalam struktur-struktur politik dalam hubungannya satu sama lain yang menunjukan suatu proses yang ajeg atau tetap. Struktur Politik diartikan sebagai suatu pola interaksi yang dianggap sah dengan mana tata masyarakat dipertahankan dan dipelihara. Struktur politik selalu berkenaan dengan alokasi nilai-nilai yang bersifat otoritatif yaitu yang dipengaruhi oleh distribusi serta penggunaan kekuasaan.

Struktur politik dapat dibedakan atas Supra Struktur Politik (Struktur Politik Pemerintahan/ SSP) dan Infra Struktur Politik (struktur Politik Masyarakat/ rakyat/ ISP). Supra struktur politik yang berbentuk lembaga formal atau resmi dengan sah menetapkan keputusan-keputusan yang mengikat anggota-anggota masyarakat untuk mencapai kepentingan umum. Infra struktur politik dalam kenyataannya merupakan mediator antara rakyat yang mengajukan tuntutan dengan para pembuat keputusan. ${ }^{14}$

Supra struktur politik dalam teori pembagian kekuasaan. Fungsi-fungsi negara atau pemerintahan dapat dilakukan dengan beberapa struktur atau dengan satu struktur. Apabila dalam penyelenggaraan fungsi Negara terpusat pada satu tangan atau struktur maka biasanya dilakukan oleh seorang diktator atau kerajaan absolut. ${ }^{15}$

Infra struktur politik yaitu struktur politik masyarakat, artinya merupakan struktur, atau bangunan, pranata yang tidak tampak secara jelas atau tidak terlihat wujudnya, namun keberadaannnya dapat dirasakan karena adanya fungsi-fungsi yang mengalir. Oleh karena itu, infra struktur politik dalam kenyataannya dapat mempengaruhi pemerintah (penguasa), dengan cara masyarakat mengemukakan, menyalurkan tuntutan, dukungan dan masalah lainnya yang menyangkut dengan kepentingan umum. Infra struktur politik terdiri dari lima komponen: ${ }^{16}$
1) Partai politik (political party)
2) Golongan kepentingan (interest group)
3) Golongan penekan (pressure group)
4) Alat komunikasi politik (media of political communication)

\footnotetext{
13 Ibid., Hlm 418

${ }^{14}$ Ibid., Hlm 5

${ }^{15}$ Beddy Iriawan Maksudi, 2012, Sistem Politik Indonesia Pemahaman Secara Teoretik Dan Empirik, Jakarta, PT Raja Grafindo Persada, Hlm 91

16 Ibid, Hlm 265
} 
5) Tokoh politik (political figure)

Fungsi-fungsi yang dilaksakan oleh supra struktur politik atau struktur pemerintahan adalah: ${ }^{17}$

1) Penetapan atau pembuatan aturan (rule making);

2) Pelaksana aturan atau undang-undang (rule application);

3) Pemberian peradilan (rule adjudication).

\section{METODE PENELITIAN}

Jenis penelitian pada tulisan ini adalah dengan menggunakan hukum doktrinal/ normatif/ positivisme. Penelitian normatif adalah penelitian hukum yang dilakukan dengan cara meneliti bahan pustaka atau data sekunder belaka. Maka teknik pengumpulan data yang dilakukan adalah dengan menggunakan teknik kepustakaan, yakni mengkaji dan menela'ah bahan-bahan pustaka dan dokumen yang ada, yang sesuai dengan bidang penelitian disertasi ini. Penelitian hukum normatif ini mencakup:18Penelitian terhadap asas-asas hukum, Penelitian terhadap sistematika hukum, Penelitian terhadapat taraf singkronisasi vertikal dan horizontal, Perbandingan hukum, Sejarah hukum.

Jenis data yang digunakan dalam penelitian ini adalah data sekunder, yang terdiri dari; bahan hukum primer, bahan hukum sekunder dan bahan hukum tersier. Data sekunder pada penelitian ini bersumber pada bahan hukum primer yaitu bahan-bahan hukum yang mengikat, terdiri dari: UUD 1945 dan Undang-Undang Nomor 2 Tahun 2011 Tentang Perubahan Atas Undang-Undang Nomor 2 Tahun 2008 Tentang Partai Politik

Langkah terakhir dalam melakukan penelitian adalah analisis data. Analisis dapat dirumuskan sebagai suatu proses penguraian secara sistematis dan konsisten terhadap gejala-gejala tertentu. ${ }^{19}$ Penguraian sistematis terhadap gejala atau data yang telah diperoleh baik melalui pendekatan kepustakaan yang akan dilakukan dengan cara deskriptif kualitatif. Data yang terkumpul dari hasil penelitian ini dianalisa secara deskriptif kualitatif, yaitu data-data yang diperoleh dalam penelitian tersebut

\footnotetext{
${ }^{17}$ Septi Nurwijayanti \& Nanik Prasetyoningsih, 2009, Politik Ketatanegaraan,Yogyakarta, Lab Hukum Universitas Muhammadiyah Sidarta, 2006, Moralitas Profesi Hukum: Suatu Tawaran Kerangka Berfikir, Bandung, Refika Aditama 18Soerjono Seokanto \& Sri Mamudji, 2001, Penelitian Hukum Normative Satu Tinjauan Singkat, Edisi1 Cetakan V, Jakarta, PT Raja Grafindo Persada, Hlm 13-14

${ }^{19}$ Soerjono Soekanto, 1982, Kesadaran Hukum Dan Kepatuhan Hukum, Jakarta, Rajawali, Hlm. 37.
} 
digambarkan dan ditata secara sistematis dalam wujud uraian-uraian kalimat yang diambil maknanya sebagai pernyatan atau kesimpulan. ${ }^{20}$

\section{PEMBAHASAN}

Sebelum membahas sebagaimana judul, perlu difahami terlebih dahulu tentang sistemm hukum. Sistem hukum adalah sebuah kajian keilmuan hukum yang sifatnya cukup istimewa. Hal ini karena sistem hukum adalah bagian dari sebuah tatanan dalam pembentukan sebuah negara dan aturan hukum yang ada di dalamnya. Dalam hal mengenal sistem hukum maka yang harus dilakukan adalah ilmu perbandingan untuk mencari perbedaan serta persamaan konsep hukum dan bernegara pada negara lain. Secara umum sistem hukum atau tatanan hukum diartikan sebagai sebuah sistem dari keseluruhan kaidah-kaidah hukum dan bentuk penampilannya dalam aturan-aturan hukum. Sistem hukum merupakan suatu sistem terbuka yang harus mampu mengakomodasi perkembangan yang terjadi dalam masyarakat. ${ }^{21}$

Pada problematika parpol di Indonesia yang belum menggunakan Pancasila sebagai asas parpol, peneliti melakukan analisa dengan menggunakan teori sistem hukum dari Lawrence Friedman. Sebagimana diketahui bahwa kondisi negara yang baik dilihat pada kondisi sistem hukum yang baik pula. Hal ini dilihat dari klasifikasi sistem hukum berdasarkan tiga teori komponen, yaitu:22

1. Substansi hukum (substance rule of the law), didalamnya melingkupi seluruh aturan baik yang tertulis maupun yang tidak tertulis, baik yang hukum material maupun hukum formal;

2. Struktur hukum (structure of the law), melingkupi pranata hukum, aparatur hukum dan sistem penegakkan hukum. Struktur hukum erat kaitannya dengan sistem peradilan yang dilaksanakan oleh aparat penegak hukum. Dalam sistem peradilan pidana, aplikasi penegakan hukum dilakukan oleh penyidik, penuntut, hakim dan advokat;

3. Budaya hukum (legal culture), merupakan penekanan dari sisi budaya secara umum, kebiasaan-kebiasaan, opini-opini, cara bertindak dan berpikir, yang mengarahkan kekuatan sosial dalam masyarakat.

\footnotetext{
${ }^{20}$ Rony Hanitijio Soemitro, Op.Cit., Hlm 82

21Ilham Bisri, 2004, Sistem Hukum Indoneisa, Prinsip-Prinsip dan Implementasi Hukum di Indonesia, Jakarta, PT Raja Grafindo Persada, Hlm. 5

${ }^{22}$ Friedman, Lawrence M. ,2013, Sistem Hukum Perspektif Ilmu Sosial (The Legal System A Social Science Perspective) Cetakan Kelima, Terjemahan M. Khozim, Bandung, Nusa Media, HIm. 12-16.
} 
Struktur hukum merupakan bagian yang memberi bentuk dan batasan terhadap keseluruhan. Bagian yang memberi bentuk tersebut adalah institusi-institusi penegakan hukum. Substansi adalah aturan, norma dan perilaku nyata manusia yang berada dalam sistem itu. Substansi bukan hanya aturan yang ada dalam peraturan perundangundangan namun mencangkup pula hukum yang hidup (living law). Selanjutnya budaya hukum merupakan suasana pikiran sosial dan kekuatan sosial yang menentukan bagaimana hukum digunakan, dihindari atau disalahgunakan. Tanpa adanya budaya hukum maka sistem hukum itu tidak berdaya, seperti ikan mati yang terkapar di keranjang dan bukan seperti ikan hidup yang berenang di laut. ${ }^{23}$

\section{Problematika Norma Landasan Partai Politik Indonesia}

Substansi hukum (substance rule of the law) melingkupi seluruh aturan baik yang tertulis maupun yang tidak tertulis, baik hukum material maupun hukum formal. Maka dalam hal ini, penulis mengkaji problematika asas parpol di Indonesia dari sudut substansi hukum. Pada Pasal 9 Undang-Undang Nomor 2 Tahun 2008 sebagaimana diubah dalam Undang-Undang Nomor 2 Tahun 2011 tentang Partai Politik, bahwa:

(1) Asas partai politik tidak boleh bertentangan dengan Pancasila dan UndangUndang Dasar Negara Republik Indonesia Tahun 1945;

(2) Partai politik dapat mencantumkan ciri tertentu yang mencerminkan kehendak dan cita-cita partai politik yang tidak bertentangan dengan Pancasila dan Undang-Undang Dasar Negara Republik Indonesia Tahun 1945;

(3) Asas dan ciri partai politik sebagaimana dimaksud pada ayat (1) dan (2) merupakan penjabaran dari Pancasila dan Undang-Undang Dasar Negara Republik Indonesia Tahun 1945.

Ketentuan dari Undang-Undang Partai Politik menegaskan bahwa parpol dapat memberi asas dan ciri tertentu yang dituangkan dalam Anggaran Dasar parpol yang mencerminkan kehendak dan cita-cita parpol selama tidak bertentangan dengan Pancasila dan UUD 1945.

Sedangkan definisi parpol sebagaimana dimuat dalam Undang-Undang Partai Politik adalah organisasi yang bersifat nasional dan dibentuk oleh sekelompok warga negara Indonesia secara sukarela atas dasar kesamaan kehendak dan cita-cita untuk 
memperjuangkan dan membela kepentingan politik anggota, masyarakat, bangsa dan negara, serta memelihara keutuhan Negara Kesatuan Republik Indonesia berdasarkan Pancasila dan UUD $1945 .^{24}$

Dari definisi di atas telah terjadi inkonsistensi norma antara pasal satu dengan pasal lainnya. Inkonsistensi tersebut mengakibatkan terjadinya inkonsistensi vertikal dalam peraturan perundang-undangan, yakni ketidaksesuaian peraturan yang berada di bawahnya dengan yang ada di atasnya. Susunan hierarki peraturan perundangundangan seyogyanya menjamin keserasian dan tidak adanya kontradiksi di antara berbagai peraturan perundang-undangan secara vertikal maupun horizontal.

Adapun analisa terhadap inkonsistensi norma dalam hierarki peraturan perundang-undangan yang dapat dijadikan alasan yuridis pada problematika sistem hukum atas asas parpol dari sudut substansi hukum adalah sebagai berikut:

a. Inkonsistensi vertikal, yaitu tidak seiramanya atau ketidaksesuaian bunyi norma antara staatsfundamentalnorm yakni Pancasila dengan peraturan di bawahnya, khususnya dalam hal ini adalah Undang-Undang Partai Politik. Telah jelas bahwa tujuan Negara Indonesia adalah sebagaimana tertuang dalam sila-sila Pancasila, yang kemudian dituangkan dalam Pembukaan UUD 1945. Konsekuensi terhadap tujuan tersebut seharusnya seluruh peraturan perundang-undangan seyogyanya juga mejadikan tujuan sebagaimana dalam ideologi dan konstitusi sebagai tujuan negara yang diimplementasikan pada seluruh regulasi di bawahnya tanpa terkecuali;

b. Inkonsistensi horizontal, yaitu tidak seiramanya atau ketidaksesuaian bunyi norma antara peraturan perundang-undangan yang kedudukannya sejajar dalam hierarki peraturan perundang-undangan. Ketidaksesuaian dalam hal ini adalah antara undang-undang dengan undang-undang. Problematika inkonsistensi itu terjadi pada Undang-Undang Mahkamah Konstitusi dengan Undang-Undang Partai Politik. Undang-Undang Partai Politik menjelaskan bahwa pada intinya parpol dapat memiliki asas dan ciri selama tidak bertentangan dengan UUD 1945 dan Pancasila. Sedangkan Undang-Undang Mahkamah Konstitusi hanya menerangkan ketika ideologi, asas, tujuan, program dan kegiatan parpol yang bertentangan dengan UUD 1945, tanpa

\footnotetext{
24 Pasal 1 ayat (1) Undang-Undang Nomor 2 Tahun 2008 sebagaimana diubah pada Undang-Undang Nomor 2 Tahun
} 2011 tentang Partai Politik 
menjelaskan tentang pertentangan parpol dengan ideologi Pancasila. Sekalipun pada Pembukaan UUD 1945 dikatakan sebagai satu kesatuan dengan pasal-pasal UUD 1945, namun kewenangan MK sebagaimana Pasal 24C UUD 1945, hanya menerangkan ketika terdapat pelanggaran parpol terhadap UUD 1945. Sehingga ketika sebuah parpol menyalahi UUD 1945 apakah otomatis parpol tersebut bertentangan dengan Pancasila. Pertanyaannya bagaimana mendudukkan Pancasila sebagai norma yang dapat dijadikan dasar hukum dalam pembubaran parpol. Undang-Undang Mahkamah Konstitusi terkait pembubaran parpol tidak satu pasal pun yang membunyikan tentang dasar Pancasila sebagai alas hukum dalam pembubaran parpol. Sedangkan Undang-Undang Partai Politik justru beberapa kali membunyikan Pancasila sebagai landasan parpol. UndangUndang Mahkamah Konstitusi dan Undang-Undang Partai Politik justru memberikan norma yang berbeda sebagai dasar pembubaran parpol di Indonesia. Oleh karena itu diperlukan rekonstruksi hukum atas asas parpol di Indonesia. Hal ini tentunya demi kepastian hukum dalam ber-partai politik.

c. Inkonsistensi norma, yaitu tidak seiramanya atau ketidaksesuaian antara pasal dalam Undang-Undang Partai Politik. Di bawah ini penulis uraikan inkonsistensi antar pasal dalam Undang-Undang Partai Politik. Sebagai bahan pembanding, penulis sertakan Undang-Undang Partai Politik terdahulu.

Pada Undang-Undang Nomor 31 Tahun 2002 dikatakan bahwa parpol adalah organisasi politik yang dibentuk oleh sekelompok warga negara Republik Indonesia secara sukarela atas dasar persamaan kehendak dan cita-cita untuk memperjuangkan kepentingan anggota, masyarakat, bangsa dan negara melalui Pemilu. Sedangkan pada Undang-Undang Nomor 2 Tahun 2008 tentang Partai Politik dikatakan bahwa parpol adalah organisasi yang bersifat nasional dan dibentuk oleh sekelompok warga negara Indonesia secara sukarela atas dasar kesamaan kehendak dan cita-cita untuk memperjuangkan dan membela kepentingan politik anggota, masyarakat, bangsa dan negara, serta memelihara keutuhan Negara Kesatuan Republik Indonesia berdasarkan Pancasila dan Undang-Undang Dasar Negara Republik Indonesia Tahun 1945.

Undang-Undang Nomor 31 Tahun 2002 memberikan definisi parpol tanpa didasari oleh landasan parpol. Dalam artian undang-undang tersebut hanya memberikan pemaknaan atas arti parpol semata. Sedangkan Undang-Undang Nomor 2 
Tahun 2008 selain secara gramatikal mengalami perubahan, juga mengalami perubahan yang cukup signifikan yaitu ditambahnya dasar atau landasan parpol yang berlaku di Indonesia yakni berlandaskan Pancasila dan UUD 1945.

Sedangkan definisi parpol pada Undang-Undang Nomor 2 Tahun 2008 telah memberikan kejelasan tentang landasan atau asas parpol, yakni berdasarkan Pancasila dan Undang-Undang Dasar 1945, maka secara tidak langsung undang-undang telah memerintahkan kepada seluruh parpol agar berlandaskan hanya pada Pancasila dan UUD 1945.

\section{KESIMPULAN}

Dari pembahasan diatas, maka dapat disimpulkan bahwa Pasal 9 ayat (1) UndangUndang Nomor 2 Tahun 2008 tentang Partai Politik menyatakan bahwa "asas parpol tidak boleh bertentangan dengan Pancasila dan UUD 1945". Hal tersebut bertentangan dengan Pasal 1 Ayat (1) pada undang-undang itu sendiri yang telah dengan tegas menyatakan parpol berdasarkan pada Pancasila dan UUD 1945. Artinya bahwa ketentuan pada Pasal 9 justru membuka peluang pada parpol untuk dapat memberikan asas selain Pancasila dan UUD 1945. Inkonsistensi norma yang terjadi antar undangundang ataupun dalam satu undang-undang jelas berdampak pada inkonsistensi implementasi yang bermuara pada perbedaan pandangan dalam memahami makna Pancasila dan UUD 1945 itu sendiri. Undang-undang partai politik seakan memiliki disorientasi norma, hal ini bisa dilihat pada beberapa bagian norma seperti pada pasal definsi partai politik, dan tafsiran asas partai politik yang dapat dikaji berdasarkan perbandingan undang-undang partai politik dari masa ke masa. Kondisi seperti ini tentunya tidak dinginkan dalam penegakkan hukum Indonesia. Norma adalah nilai pasti dalam penegakkan hukum, oleh karenanya norma tidak bisa memiliki makna yang beragam, apalagi tergantung dari pada pelaksana undang-undang. 


\section{DAFTAR PUSTAKA}

\section{Buku-buku}

Beddy Iriawan Maksudi, 2012, Sistem Politik Indonesia Pemahaman Secara Teoretik Dan Empirik, Jakarta, PT Raja Grafindo Persada.

Friedman, Lawrence M. ,2013, Sistem Hukum Perspektif Ilmu Sosial (The Legal System A Social Science Perspective) Cetakan Kelima, Terjemahan M. Khozim, Bandung, Nusa Media.

Imam Hidayat, 2009, Pengantar Teori-Teori Politik, Setara Press, Malang.

Ilham Bisri, 2004, Sistem Hukum Indoneisa, Prinsip-Prinsip dan Implementasi Hukum di Indonesia, Jakarta, PT Raja Grafindo Persada.

Jimly Asshiddiqie, 2008, Menuju Negara Hukum Yang Demokrastis, Jakarta, Sekretariat Jendal Dan Kepanitraan Mahkamah Konstitusi.

Muhammad Imarah, 1419, Ma'rakatul Mushthalathat Baina Al-Gharbi Wa Islami, Kairo, Nahdhah Mishr.

Moh. E. Hasim, 1987, Kamus Istilah Islam, Bandung, Pustaka.

Miriam Budiardjo, 2012, Dasar Dasar Ilmu Politik Cetakan Kedua, Jakarta, PT. Gramedia Pustaka Utama.

Ronny Hanityo Soemitro, 1998, Metodologi Penelitian Hukum Dan Jurimetri, Jakarta, Ghalia Indonesia.

Septi Nurwijayanti \& Nanik Prasetyoningsih, 2009, Politik Ketatanegaraan,Yogyakarta, Lab Hukum Universitas Muhammadiyah Sidarta, 2006, Moralitas Profesi Hukum: Suatu Tawaran Kerangka Berfikir, Bandung, Refika Aditama.

Sigit Pamungkas dalam buku Sirajudin \& Winardi, 2015, Dasar-Dasar Hukum Tata Negara Indonesia, Malang, Setara Press.

Soerjono Seokanto \& Sri Mamudji, 2001, Penelitian Hukum Normative Satu Tinjauan Singkat, Edisi1 Cetakan V, Jakarta, PT Raja Grafindo Persada.

Soerjono Soekanto, 1982, Kesadaran Hukum Dan Kepatuhan Hukum, Jakarta, Rajawali.

\section{Artikel}

Imam Yudhi Prasetya, 2011, Pergeseran Peran Ideologi Dalam Partai Politik, Jurnal Ilmu Politik dan Ilmu Pemerintahan, Tanjungpinang, Universitas Maritime Raja Ali Haji, Vol 1, No 1.

\section{Data internet}

Muqoddam

cholil,

partai

islam, http://www.alhikmah.ac.id/soft/Artikel/Kontemporer/partaiislam.pdf, diakses pada 2 Agustus 2020. 


\section{Peraturan perundang-undangan}

Undang-Undang Nomor 2 Tahun 2008 sebagaimana diubah pada Undang-Undang Nomor 2 Tahun 2011 tentang Partai Politik. 